\title{
On the Knowledge Regarding ill Effects and Attitude towards using High Heel Foot Wear among Adolescent Girls
}

\author{
Payal R. Burbure and Deeplata Mendhe \\ Department of Community Health Nursing. SRMM College of Nursing, \\ Datta Meghe Institute of Medical Sciences, Sawangi (M), Wardha Corresponding author email: mendhedeeplata@gmail.com
}

\begin{abstract}
Adult hood is a transitional stage of physical and psychological in human life. An adult is exposed to number of images and ideas of what they are "supposed" to look like and act like. Health is the level of functional or metabolic efficiency of a living being. In human, it is the general condition of a person's mind and body, usually meaning to be free from illness, injury or pain. High heels are a fashionable foot ware; every woman loves to look tall, sexy, having long legs but after putting the high heels she is compromising her foot as well as on her posture. Fashion is like a circle; it keeps on changing and reaches the same position after some time. So is the foot ware it also changes with time. Present time is of high heels, a person wearing high heels, the center of gravity changes to forward and the buttocks and spine is out of alignment. assess the knowledge and attitude regarding ill effects of using high heel footwear among adolescent girls. correlate knowledge regarding ill effects and attitude towards using high heel footwear among adolescent girls. associate the knowledge and attitude score with selected demographic variables. Descriptive research design is used in this research Setting is the physical location and condition in which data collection takes place. This study is conducted in selected colleges of Wardha city. findings show the correlation coefficient ' $r$ ' 0.017 is a poor level of correlation. The correlation coefficient $r$, always lies between -1 and +1 . i.e. $-1 \leq r \leq 1$. The ' $r$ ' for given data is calculated as 0.017 . Hence, it is statistically interpreted that there is a poor positive correlation between knowledge and attitude of adolescent girls regarding ill effects of high heels footwear. Findings suggest that adolescent girls are not sufficiently aware about the ill effects of using and somewhat their attitude is positive towards use of high heels footwear.
\end{abstract}

KEY WORDS: TRANSITIONAL, PSYCHOLOGICAL, COMPROMISING, HIGH HEELS, BUTTOCKS

\section{INTRODUCTION}

High heels are a fashionable foot ware; every woman loves to look tall, sexy, having long legs but after putting the high heels she is compromising her foot as well as on her posture. Fashion is like a circle; it keeps on changing and reaches the same position after some time. So is the foot ware it also changes with time. Present time is of high heels, a person wearing high heels, the center of gravity changes to forward and the buttocks and spine is out of alignment. Long use of High heels tends to increase the

Biosc Biotech Res Comm P-ISSN: 0974-6455 E-ISSN: 2321-4007
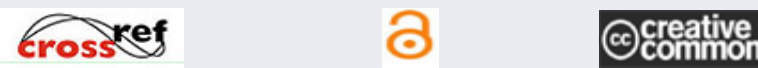

Identifiers and Pagination

Article Information

Year: 2021 Vol: 14 No (9) Special Issue

Pages: 299-304

Received: $18^{\text {th }}$ Apr 2021

This is an open access article under Creative

Commons License Attribn 4.0 Intl (CC-BY).

DOI: $h t t p: / / d x . d o i . o r g / 10.21786 / b b r c / 14.9 .55$ size of buttocks. A high heel also pushes the buttocks of women high and with time the figure changes.

High heels are worn by many women worldwide to enhance their professional and physical appearance, yet their damaging effects, exceeds the discomfort, many women bear to tolerate while wearing such elevated shoes. The American Podiatric Medical Association provides statistics that 39 per cent of the female population wears high-heeled shoes every day, and that doesn't count those who wear them now and again. The results are that, three quarters of this group of women suffer with a type of foot problem caused by high-heeled shoes. A study was done to examine the gait of regular heel wears compared to non wears in the year 2012, recruiting 10 non wearers and 9 regular heel wears (40+hours per week) clear gait and biomechanical difference become evident.

High-heeled footwear (often abbreviated as high heels or simply heels) is footwear that raises the heel of the wearer's foot significantly higher than the toes. When

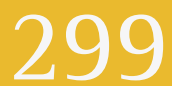


both the heel and the toes are raised equal amounts, as in a platform shoe, it is technically not considered to be a high heel; however, there are also high-heeled platform shoes. High heels tend to give the aesthetic illusion of longer, more slender legs. High heels come in a wide variety of styles, and the heels are found in many different shapes, including stiletto, pump (court shoe), block, tapered, blade, and wedge.

According to high-fashion shoe websites like Jimmy Choo and Gucci, a low heel is considered less than 2.5 inches ( 6.4 centimeters), while heels between 2.5 and 3.5 inches $(6.3$ and $8.9 \mathrm{~cm})$ are considered mid heels, and anything over is considered a high heel. The apparel industry would appear to take a simpler view; the term high heels cover heels ranging from 2 to 5 inches. Extremely highheeled shoes, such as those exceeding 6 inches, strictly speaking, are no longer considered apparel but rather something akin to jewellery for the feet. They are worn for display or the enjoyment of the wearer. Wearing high heels $(\mathrm{HH})$ places the calf muscle-tendon unit (MTU) in a shortened position. As muscles and tendons are highly malleable tissues, chronic use of high hills might induce structural and functional changes in the calf MTU. To test this hypothesis, 11 women regularly wearing $\mathrm{HH}$ and a control group of 9 women were recruited.

Gastronomiesmedialis (GM) fascicle length, pinnation angle and physiological cross-sectional area (PCSA), the Achilles' tendon (AT) length, cross-sectional area (CSA) and mechanical properties, and the plantar flexion torque-angle and torque-velocity relationships were assessed in both groups. They conclude that long-term use of high-heeled shoes induces shortening of the GM muscle fascicles and increases at stiffness, reducing the ankle's active range of motion. High heels are bad for body as they throw weight onto the ball of the foot; lead to Callus, painful bunions, corns and deformity. They may also push the center of mass in the body forward, causing the spine to bend backwards to recompense, which can lead to back problems. Other problems with high heels are that the position of the foot in the shoe and narrow heel width can cause the ankle to become unstable, resulting in ankle sprains or the calf muscles shortening. This is especially true for those wearing high heels for over 6 months and the body compensating for this tightness by lowering the arch of the foot, or affecting the knee, hip or back (Kumar et al., 2015).

A study was done to assess the effect of the use of highheeled shoes on static balance in young adult women in the year 2012. Fifty-three women between 18 and 30years of age and accustomed to wear high-heeled shoes participated in the study. None of the participants had any orthopedic or neurologic alterations. Static balance was assessed using a force plate. Heels force the thigh muscles to work harder, putting extra strain on the knee joint and tendon that runs from the knee cap to the thigh bone. Compared with walking barefoot, high heels increase the pressure on the inside of the knee by 26 percent. Over time, this increased pressure on the knee can lead to osteoarthritis. As a result, heels can lead to bunions, heel pain, toe deformities, shortened Achilles's tendons, and trapped nerves. In fact, women account for about $90 \%$ of the nearly 800,000 operations each year for bunions, hammertoes (a permanent deformity of the toe joint in which the toe bends up slightly and then curls downward, resting on its tip), and trapped nerves, and most of these surgeries can be linked back to their high-heeled shoe choice (Blanco et al., 2015).

Reasons for wearing high heels, which are almost exclusively aesthetic reasons, include: They change the angle of the foot with respect to the lower leg, which accentuates the appearance of calves; they change the wearer's posture, requiring a more upright carriage and altering the gait in what is considered a seductive fashion. They make the wearer appear taller, foot appears smaller and toes appear shorter. Reasons of wearing high heels, which are almost exclusively health and practicality reasons, include: they can cause foot pain, increase likelihood of sprains and fractures. They can cause an unsteady gait. They can shorten the wearer's stride. Women who wear high heels frequently have a higher incidence of degenerative joint disease of the knees. This is because they cause a decrease in the normal rotation of the foot, which puts more rotation stress on the knee. A high heel also puts pressure on the inner side of knees. Study by the health experts says women wearing high heels put $26 \%$ of pressure more on the knees. As a result, the osteoarthritis is seen common in women wearing high heels (Cronin 2014).

\section{MATERIAL AND METHODS}

Research Design: Descriptive research design is used. Descriptive design involves the accurate description of characteristics of individual, situation, or group, and the frequency with which a certain phenomenon occurs in natural setting without imposing any control or manipulation (Pazhoohi et al., 2018).

Setting Of the Study: This study is conducted in selected colleges of Wardha city. The investigator found the setting appropriate to conduct the study as adequate numbers of adolescent girls were available who could be taken as sample for the study (Steele 2015).

Sampling Technique: The sampling technique used in the study was non-probability convenience sampling. Convenience sampling is a non- probability sampling technique where subjects are selected just because of their convenient accessibility and proximity to the researcher (Tedeschi et al., 2012).

\section{RESULTS AND DISCUSSION}

Table no. 2 shows that No one have excellent knowledge. $1(0.5 \%)$ of them had poor level of knowledge, 137(68.5\%) of them had average level of knowledge and $62(31 \%)$ of them had good level of knowledge score and $0(0 \%)$. The 
minimum score was 5 and the maximum score was 18 , the mean score for the test was $11.31 \pm 2.555$ and mean percentage of knowledge was 47.125 . Therefore, $\mathrm{H} 1$ is accepted (Wade 2013).

Table 1. Percentage wise distribution of adolescent girls according to their demographic variables $n=200$

\begin{tabular}{|l|c|c|c|}
\hline Sr. no. & $\begin{array}{c}\text { Demographic } \\
\text { Variables }\end{array}$ & Frequency & Percentage (\%) \\
\hline 1. & & Age (Yrs) & \\
& 16 & 42 & $21 \%$ \\
& 17 & 123 & $61.5 \%$ \\
& 18 & 28 & $14 \%$ \\
& 19 & 7 & $3.5 \%$ \\
\hline 2. & & Residential area & \\
\hline & Urban & 100 & $50 \%$ \\
\hline 3. & Kural & 100 & $50 \%$ \\
\hline & & 103 & $51.5 \%$ \\
& $5001-10000$ & 63 & $11 \%$ \\
& $10001-15000$ & 12 & $6 \%$ \\
\hline 4. & $15001<$ & 100 & \\
& & Family income in Rs. & $50 \%$ \\
& Yes & Do you wear high heels footwear? & $50 \%$ \\
\hline & & 100 & \\
\hline
\end{tabular}

Table 2. Level of knowledge score of adolescent girls regarding ill effects of using high heels footwear $n=200$

\begin{tabular}{l|c|c|c|c|}
\hline \multirow{2}{*}{$\begin{array}{l}\text { Level of knowledge } \\
\text { score }\end{array}$} & Score & \multirow{2}{*}{ Percentage score } & \multicolumn{2}{|c|}{ Knowledge score } \\
\cline { 4 - 5 } & & & Frequency & Percentage \\
\hline Poor & $0-6$ & $0-25 \%$ & 1 & $0.5 \%$ \\
\hline Average & $7-12$ & $26-50 \%$ & 137 & $68.5 \%$ \\
\hline Good & $13-18$ & $51-75 \%$ & 62 & $31 \%$ \\
\hline Excellent & $19-24$ & $76-100 \%$ & 0 & $0 \%$ \\
\hline Minimum score & 5 & & & \\
\hline Maximum score & 18 & & & \\
\hline Mean score & $11.31 \pm 2.555$ & & & \\
\hline Mean Percentage & 47.125 & & & \\
\hline
\end{tabular}

Figure 1: Level of knowledge score of adolescent girls regarding ill effects of high heels footwear.

\section{Level of knowledge score}

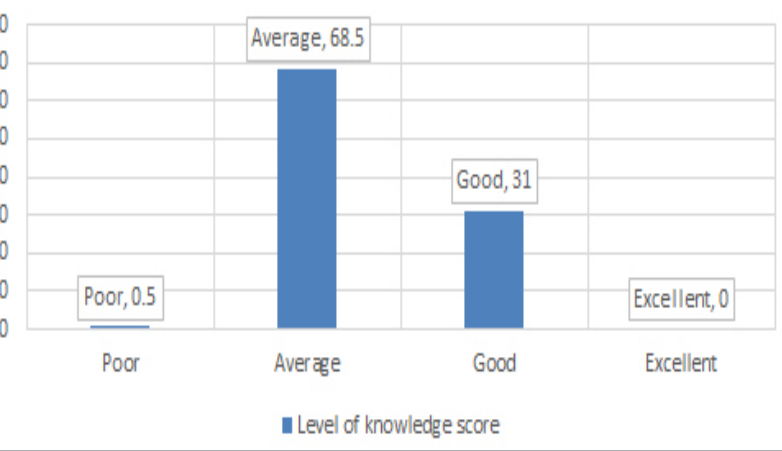

Figure 2: Level of attitude score of adolescent girls towards using of high heels footwear. ( $80 \%$ samples shows Positive attitude about not wearing high heels footwear.)

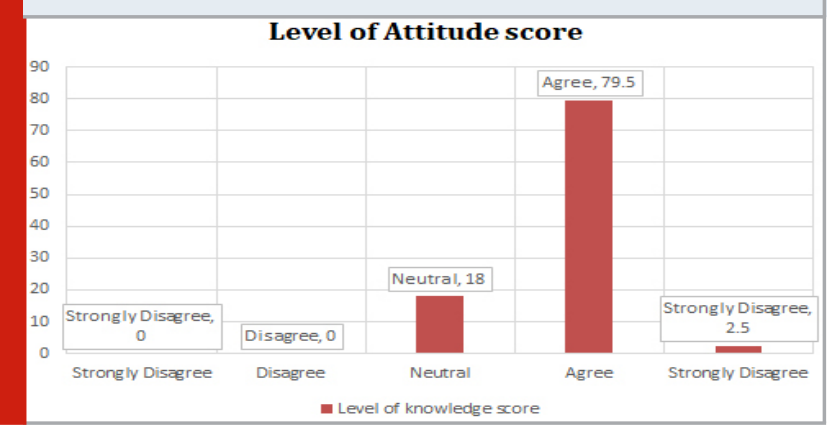


Table 3. Level of attitude score of using high heels footwear among adolescent girls. $\mathrm{n}=200$

\begin{tabular}{l|c|c|c|}
\hline \multirow{2}{*}{$\begin{array}{l}\text { Level of Attitude } \\
\text { score }\end{array}$} & \multirow{2}{*}{ Score } & \multicolumn{2}{|c|}{ Attitude score } \\
\cline { 3 - 4 } & & Frequency & Percentage \\
\hline Strongly disagree & $1-18$ & 0 & $0 \%$ \\
\hline Disagree & $19-36$ & 0 & $0 \%$ \\
\hline Neutral & $37-54$ & 36 & $18 \%$ \\
\hline Agree & $55-72$ & 159 & $79.5 \%$ \\
\hline Strongly agree & $73-90$ & 5 & $2.5 \%$ \\
\hline Minimum score & \multicolumn{3}{|c|}{44} \\
\hline Maximum score & \multicolumn{3}{|c|}{$78.74 \pm 6.413$} \\
\hline $\begin{array}{l}\text { Mean score } \\
\text { Mean Percentage }\end{array}$ & \multicolumn{3}{|c|}{67.48} \\
\hline
\end{tabular}

Figure 3: Correlation between knowledge regarding ill effects and attitude towards using high heels footwear among adolescent girls.

Correlation between knowledge regarding ill effects and attitude towards using high heels footwear among adolescent girls

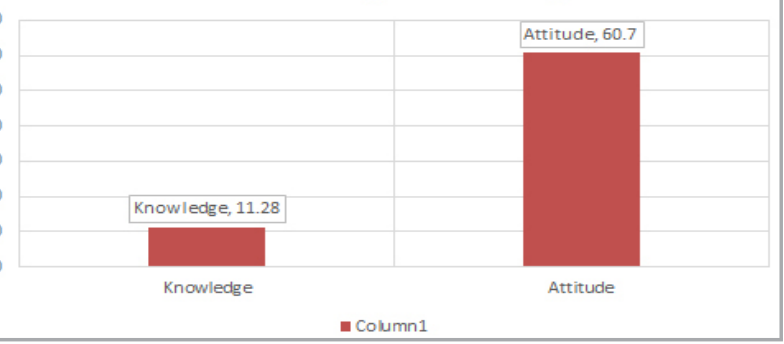

Table no. 3 shows the frequency and percentage wise distribution of adolescent girls according to level of attitude towards using high heels footwear. The levels of attitude were seen into 5 categories, strongly agree, agree, neutral, disagree and strongly disagree. None of the adolescent girls were "Strongly disagree" and none of the adolescent girls were "Disagree", 36 (18\%) of the adolescent girls were "Neutral", 159 (79.5\%) of the adolescent girls were "Agree" and 5 (2.5\%) of the adolescent girls were "Strongly agree" about attitude score. The minimum score was 44 and the maximum score was 78, the mean score for the test was $60.74 \pm$ 6.413 and mean percentage of knowledge was 67.48 . Therefore, $\mathrm{H} 2$ is accepted.

Table 4. Correlation between knowledge scores and attitude scores of ill effects of using high heels footwear among adolescent girls. $n=200$

\begin{tabular}{|lccc|c|}
\hline Overall & Mean & SD & Mean Percentage & $\begin{array}{c}\text { Correlation coefficient } \\
\text { 'r' value }\end{array}$ \\
\hline Knowledge & 11.28 & 2.555 & 47 & 0.017 \\
\hline Attitude & 60.70 & 6.492 & 67.44 & \\
\hline
\end{tabular}

Table no. 4 shows the correlation coefficient ' $r$ ' 0.017 is indicate a poor level of correlation. (The correlation coefficient $r$, always lies between -1 and +1 . i.e. $-1 \leq r$ $\leq 1$.) The ' $r$ ' for given data is calculated and it is 0.017 . Hence, it is statistically interpreted that there is a poor positive correlation between knowledge regarding ill effects and attitude towards using high heels footwear among adolescent girls.

A study on High Heels Footwear Causes Heel Pain and Back Pain: Myth or Reality? The study showed footwear is defined as the footwear having a heel that is higher than the toe. Throughout the history, this footwear is considered as a symbol of sexuality, class and gender. When the foot slants forward, a much greater weight is transferred to the ball of the foot and toes, which increases the likelihood of damage to the underlying soft tissues that supports the foot. When the wearer tips the foot forward, this in turn puts pressure on the lower back and hence causes back pain. This particular study on post adolescent volunteers was aimed to study the correlation between heeled footwear and heel and back pain. study was conducted on 100 female patients who attended orthopedic outpatient department at institution during the period from July 2014 to December.

Walking is the most common form of human locomotion from a motor control perspective, human bipedalism makes the task of walking extremely complex. One condition known to compound the difficulty of walking is the use of heeled shoes, which alters the natural position of the foot-ankle complex. This thereby produces a chain of reaction effects that travels up to the lumbar vertebrae. Heeled footwear has been in use by women 
for centuries and has now become an integral part of the wardrobe not only in the west but also in India. Recent research suggests that up to one third of women suffer from permanent problems as a result of their prolonged wearing of heels. One in 10 women wear it at least for 3 days a week, and a recent survey found that one-third of them had permanent problems. Whether the high heel wear is the actual cause of back pain is not yet clear. Literatures vary in their results regarding the same.

Table 5. Association of Knowledge Score with Selected Demographic Variable $n=200$

\begin{tabular}{|c|c|c|c|c|}
\hline Age (yrs) & No. of adolescent girls & Mean knowledge score & F-value & $\mathrm{p}$-value \\
\hline $\begin{array}{l}16 \mathrm{yrs} \\
17 \mathrm{yrs} \\
18 \mathrm{yrs} \\
19 \mathrm{yrs}\end{array}$ & $\begin{array}{c}42 \\
123 \\
28 \\
7\end{array}$ & $\begin{array}{l}11.24 \pm 2.721 \\
11.33 \pm 2.635 \\
11.43 \pm 1.874 \\
10.86 \pm 2.911\end{array}$ & 0.106 & $\begin{array}{c}0.956 \\
\mathrm{NS}, \mathrm{p}>0.05\end{array}$ \\
\hline $\begin{array}{l}\text { Residential Area } \\
\text { Urban } \\
\text { Rural }\end{array}$ & $\begin{array}{l}\text { No. of adolescent girls } \\
100 \\
100\end{array}$ & $\begin{array}{c}\text { Mean knowledge score } \\
11.44 \pm 2.337 \\
11.18 \pm 2.761\end{array}$ & $\begin{array}{c}\text { t-value } \\
0.719\end{array}$ & $\begin{array}{c}\mathrm{p} \text {-value } \\
0.52 \\
\text { NS, } \mathrm{p}>.0 .05\end{array}$ \\
\hline $\begin{array}{l}\text { Family Income (Rs.) } \\
<5000\end{array}$ & $\begin{array}{l}\text { No. of adolescent girls } \\
103\end{array}$ & $\begin{array}{c}\text { Mean knowledge score } \\
11.50 \pm 2.715\end{array}$ & $\begin{array}{c}\text { F-value } \\
0.914\end{array}$ & $\begin{array}{c}\mathrm{p} \text {-value } \\
0.435 \\
\mathrm{~s}, \mathrm{p}<0.05\end{array}$ \\
\hline $\begin{array}{l}5001-10000 \\
10001-15000 \\
15001<\end{array}$ & $\begin{array}{l}63 \\
22 \\
12\end{array}$ & $\begin{array}{l}10.87 \pm 2.345 \\
11.45 \pm 1.765 \\
11.67 \pm 3.339\end{array}$ & & \\
\hline $\begin{array}{l}\text { Wearing High heels } \\
\text { Yes } \\
\text { No }\end{array}$ & $\begin{array}{l}\text { No. of adolescent girls } \\
100 \\
100\end{array}$ & $\begin{array}{c}\text { Mean knowledge score } \\
11.44 \pm 2.337 \\
11.18 \pm 2.761\end{array}$ & $\begin{array}{c}\text { t-value } \\
0.719\end{array}$ & $\begin{array}{c}\mathrm{p} \text {-value } \\
0.052 \\
\mathrm{NS}, \mathrm{p}>0.05\end{array}$ \\
\hline
\end{tabular}

Table 6. Association of Attitude Score with Selected Demographic Variables.

\begin{tabular}{|c|c|c|c|c|}
\hline Age (yrs) & No. of adolescent girls & Mean knowledge score & F-value & p-value \\
\hline 16 yrs & 42 & $60.45 \pm 6.946$ & 0.241 & 0.867 \\
\hline $17 \mathrm{yrs}$ & 123 & $60.66 \pm 6.198$ & & NS, $p>0.05$ \\
\hline $18 \mathrm{yrs}$ & 28 & $61.14 \pm 6.587$ & & \\
\hline 19 yrs & 7 & $62.80 \pm 7.727$ & & \\
\hline Residential Area & No. of adolescent girls & \multirow{3}{*}{ 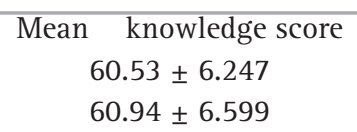 } & t-value & p-value \\
\hline Urban & 100 & & 0.410 & 0.253 \\
\hline Rural & 100 & & & NS, $p>.0 .05$ \\
\hline Family Income (Rs.) & No. of adolescent girls & \multirow{5}{*}{$\begin{array}{c}\text { Mean knowledge score } \\
60.68 \pm 6.219 \\
61.71 \pm 6.798 \\
60.68 \pm 5.186 \\
56.17 \pm 6.726\end{array}$} & F-value & p-value \\
\hline$<5000$ & 103 & & 2.583 & 0.055 \\
\hline $5001-10000$ & 63 & & & NS, $p>0.05$ \\
\hline $10001-15000$ & 22 & & & \\
\hline $15001<$ & 12 & & & \\
\hline Wearing High heels & No. of adolescent girls & \multirow{3}{*}{$\begin{array}{l}\text { Mean knowledge score } \\
60.53 \pm 6.247 \\
60.94 \pm 6.599\end{array}$} & t-value & p-value \\
\hline Yes & 100 & & 0.451 & 0.253 \\
\hline No & 100 & & & NS, $p>0.05$ \\
\hline
\end{tabular}

Hence, the present study was done to assess this cause and effect. The study was conducted at the orthopedic outpatient department of a tertiary care hospital, from July 2014 to December 2014.100 female patients who were using heeled shoes and who volunteered to participate in the study were included. The heel height was measured using measuring tape and was classified into three groups (5 cm). A Performa with a questionnaire was given to all the participants and their responses were noted. Out of the 100 female volunteers, who participated in the study, 44 had complaints of heel pain regardless of the heel height, 56 had back pain, and many had both heel pain 
and back pain complaints, based on the questionnaire evaluation. We were further able to distinguish both heel pain and back pain, based on the heel height worn, duration of wear (in years) and duration worn/day. There was a positive correlation between duration of wear and height of footwear with regards to both heel and back pain. However, a definitive cause and effect could not be established because of smaller sample size.

\section{CONCLUSION}

Much of the previous research on high heels footwear has focused on the clinical and technical processes and has not sought out the views of adolescent girls, despite this age group is more concerned with the fashion and inclined to the high heel's footwear. Findings suggest that adolescent girls are not sufficiently aware about the ill effects of using and somewhat their attitude is positive towards use of high heels footwear.

Declaration of Conflicting Interests: The authors declared no potential conflicts of interest concerning the research, authorship, and/or publication of this article.

Funding: The authors received no financial support for the research, authorship, and/or publication of this article.

\section{REFERENCES}

Blanco, J., Hunt-Hurst, P.K., Lee, H.V. and Doering, M. eds., (2015). Clothing and fashion: American fashion from head to toe [4 volumes]: American fashion from head to toe. ABC-CLIO.

Cronin, N.J., (2014). The effects of high heeled shoes on female gait: a review. Journal of electromyography and kinesiology, 24(2), pp.258-263.

Kumar, N.V., Prasanna, C., Sundar, V.S. and Venkatesan, A., (2015). High heels footwear causes heel pain and back pain: myth or reality. International Journal of Scientific Study, 3(8), pp.101-104.

Pazhoohi, F., Doyle, J.F., Macedo, A.F. and Arantes, J., (2018). Arching the back (lumbar curvature) as a female sexual proceptivity signal: An eye-tracking study. Evolutionary Psychological Science, 4(2), pp.158-165. Steele, V. ed., (2015). The Berg companion to fashion. Bloomsbury Publishing.

Tedeschi Filho, W., Dezzotti, N.R., Joviliano, E.E., Moriya, T. and Piccinato, C.E., (2012). Influence of high-heeled shoes on venous function in young women. Journal of vascular surgery, 56(4), pp.1039-1044.

Wade, L., (2013). From manly to sexy: The history of the high heel. The Huffington Post. 